Omni-Akuatika, 16 (2): 141 -150, 2020
ISSN: 1858-3873 print / 2476-9347 online
Research Article
journal homepage: http://ojs.omniakuatika.net

\title{
Species Composition and Distribution of Tropical Marine Macroalgae In The Pari Island Reef Cluster, Jakarta
}

\author{
Firman Zulpikar*, Tri Handayani, Jeverson Renyaan, Husen Rifai, Bayu Perisha
}

Research Center for Oceanography - Indonesian Institute of Sciences (RCO-LIPI)

*Coresponding author: firman.zulpikar@lipi.go.ig

Received 22 September; Accepted 30 October 2020; Available online 31 December 2020

\begin{abstract}
The objective of this study was to analyze the species composition and distribution of marine macroalgae at Pari Island reef cluster-Seribu Islands reef system Jakarta based on specimen information available in Reference Collection of Research Center for Oceanography (RCO-LIPI). The Macroalgae specimens were collected irregularly by researchers during marine expedition projects from 1973 until 2014. Taxonomic identification of specimens was conducted in 2014, validation of species names was updated in May 2020 through www.macroalgaebase.org. The floristic composition value of macroalgae was analyzed using the $C / P, R / P$, and $(R+C) / P$ ratio. Bray-Curtis similarity index analyzes were performed to visualize differences in macroalgae species from the different islands. We recorded a total of 41 species from 25 genus and 18 families. Rhodophyta represented the most significant number of taxa with 20 species (49\%), followed by Chlorophyta with 11 species $(27 \%)$ and Phaeophyta with ten species (24\%). In this study, we found that Sargassum polycystum, Gracilaria salicornia, Amphiroa fragilisima, and Halimeda opuntia are dominant species in the study area. The highest macroalgae diversity found in Kongsi Island with 33 species, while the lower diversity found in Pari Island with five species. Bray-Curtis Similarity index showed that Kongsi Island and Burung Island have the highest similarity value with $29,26 \%$, while Tikus Island and Pari Island have the lowest similarity value with $11,76 \%$. The macroalgae distribution in the Pari island reef cluster influenced by the difference of substrate profile and environmental pressure derived from human activities. Proper management of macroalgae resources is necessary to preserve the sustainability of the macroalgae ecosystem.
\end{abstract}

Keywords: macroalgae, composition, distribution, Pari Island

\section{ABSTRAK}

Tujuan penelitian ini adalah untuk menganalisa komposisi spesies dan distribusi makroalga laut di Gugusan Pulau Pari-Kepulauan Seribu, Jakarta berdasarkan informasi spesimen yang tersedia di fasilitas Koleksi Referensi Pusat Penelitian Oseanografi (PPO-LIPI). Spesimen makroalga dikumpulkan secara tidak teratur oleh para peneliti selama proyek ekspedisi laut dari tahun 1973 sampai tahun 2014. Identifikasi taksonomi spesimen dilakukan pada tahun 2014, sedangkan validasi dan pembaharuan nama spesies dilakukan pada Bulan Mei 2020 menggunakan informasi yang tersedia pada situs www.macroalgaebase.org. Nilai komposisi floristik dari makroalga dianalisis dengan menggunakan rasio $\mathrm{C} / \mathrm{P}, \mathrm{R} / \mathrm{P}$, dan $(\mathrm{R}+\mathrm{C}) / \mathrm{P}$. Analisis Indeks kesamaan Bray-Curtis dilakukan untuk memvisualisasikan perbedaan dalam spesies alga dari pulau yang berbeda. Kami berhasil mencatat total 41 spesies makroalga yang terbagi atas 25 genus dan 18 famili. Rhodophyta mewakili jumlah taksa paling banyak dengan 20 spesies (49\%), diikuti oleh Chlorophyta dengan 11 spesies (27\%) dan Phaeophyta dengan 10 spesies (24\%). Dalam studi ini, Sargassum polycystum, Gracilaria salicornia, Amphiroa fragilisima, dan Halimeda Opuntia merupakan spesies dominan di wilayah kajian. Jumlah spesies alga tertinggi ditemukan di Pulau kongsi yaitu 33 spesies, sementara jumlah spesies terendah ditemukan di Pulau Pari yaitu 5 spesies. Indeks Similaritas Bray-Curtis menunjukkan bahwa Pulau Kongsi dan Pulau Burung memiliki nilai kesamaan spesies tertinggi mencapai 29,26\%, sedangkan Pulau Tikus dan Pulau Pari memiliki nilai kesamaan spesies terendah yaitu sebesar $11,76 \%$. Distribusi makroalga di Gugusan Pulau Pari terlihat dipengaruhi oleh perbedaan profil 
substrat dan tekanan lingkungan yang berasal dari aktivitas manusia. Pengelolaan ekosistem pesisir yang tepat diperlukan untuk menjaga kelestarian sumberdaya makroalga.

Kata Kunci: makroalga, komposisi, distribusi, Pulau Pari,

\section{Introduction}

The Indonesian coastal zone is rich in tropical marine ecosystems such as estuarial, salt marshes, seagrass meadows, mangroves, coral reefs, and small island ecosystems which are homes of different varieties of living communities. The different characteristics of the Indonesian marine environment provide various types of marine habitats for benthic marine organism communities (Hutomo and Moosa, 2005). One of the benthic marine organism mainly found in Indonesian waters is macroalgae, commonly called the seaweeds. Macroalgae are one of the important primary producers of the sea (Sudhakar et al., 2018). The organism contains chlorophyll for photosynthesis process and few pigments (Simatupang et al., 2018).

Basically, marine macroalgae are available in the diverse group with a common structure, only difference they do not have actual leaves, stems, and roots (Sudhakar et al., 2018). They are simplistically categorized into green macroalgae (Chlorophyta), brown macroalgae (Phaeophyta or Ochrophyta) and red macroalgae (Rhodophyta). Most macroalgae need a hard substrate to attach to and the dominant substrate inshore mainly consists of sand, silt and shifting rubble (Rachello-Dolmen and Cleary, 2007), sessile, and easy to observe because they need to be exposed to sunlight (Draisma et al., 2017). Macroalgae found attached to the bottom, in relatively shallow coastal waters areas up to 180 meter depth (Sahayaraj and Sathiyamoorthy, 2014).

Benthic marine macroalgae is widespread in almost all regions of Indonesia. Some regions such as the Seribu Islands reef complex are considered to have high macroalgae biodiversity. Therefore, research efforts in these regions are quite intensive. Seribu Islands reef system located in the northwest of Jakarta Bay, Indonesia. The reef system consists of 101 islands, which are divided into several island clusters that are close together. Investigation on biodiversity of macroalgae in the Seribu Islands was initiated by Atmadja in 1955 and some of its species findings have been described in the book "Pengenalan Jenis-jenis rumput laut di Indonesia" (Atmadja et al., 1996). In the next years, the number of efforts to explore marine biodiversity in the Seribu Islands reef system were continued by researchers from the Research Center for Oceanography, Indonesian Institute of Sciences (RCO-LIPI), during marine expeditions and managed to collect a number of the marine organism including macroalgae which are currently stored in the Reference collection facility of RCO LIPI. Much scientific knowledge have been published regarding marine flora and fauna in Seribu Islands reef system. However, reports on macroalgae diversity in specific island clusters in the Seribu Islands are still lacking. Recently we have identified the amount of macroalgae specimens collected from the Pari Island reef cluster, part of the Seribu Islands. The main objectives of the study were to report and analyze the taxonomic inventory of macroalgae and its distribution in the Pari Island reef cluster based on specimens information provided by the Reference Collection facility in RCO-LIPI, Indonesia. This study provides valuable information on marine macroalgae biodiversity particularly in the western region of Indonesia.

\section{Method}

\subsection{Study Area}

The Pari Island reef cluster is a part of the Seribu Island reef system. The reef cluster consists of Pari Island, Kongsi Island, Tengah Island, Burung Island, and Tikus Island surrounded by atoll coral reefs (figure 1). The formation of the mainland of the islands in the Pari Island group is inseparable from the vertical growth of coral reefs, the accumulation of sediments due to the process of coral reef disintegration and coastal abrasion by waves, the influence of coastal shore currents and due to human intervention greatly influence the formation of the island landscape within Pari Island reef cluster. The condition of the waters in the area outside the atoll is a deep water area while the waters inside the atoll are relatively sloping areas, and in some places, there are lagoons (lagoon). Geographically, the Pari Island Group is located between $05^{\circ} 50$ 'LS to $05^{\circ} 53^{\prime} \mathrm{LS}$ and $106^{\circ} 34$ 'BT to $106^{\circ} 38^{\prime}$ BT. This area is located in the Java Sea, 
precisely north of DKI Jakarta and Tangerang. Administratively, the Pari Islands include Kelurahan Tidung Island, Seribu Islands District, Jakarta Province (Salim and Ahmad, 2013).

\subsection{Data Sources}

We used the macroalgae specimens that available in Reference Collection facility of Research Center for Oceanography (RCO LIPI), Indonesia. Macroalgae specimens from four island of Pari Island reef cluster namely Pari Island, Burung Island, Kongsi Island, and Tikus Island were collected irregularly and randomly by several Researcher during marine expedition projects. The specimens were collected, preserved and placed at Macroalgae Reference Collection facility for further taxonomy identification work.

\subsection{Data Analysis}

A literature review, validation of specimen's information, and personal communication with previous researchers were carried out intensely. Species lists of macroalgae collected from the Pari Island reef cluster are reviewed for their taxonomic group, latest species naming, and morphological characteristics through www.algaebase.org. Because the specimens record that available in reference collection are taxonomic inventory within an island, and no have information regarding its abundance. Thus, the analysis of community structure and distribution in this study only includes species composition and species similarity. We used the $\mathrm{C} / \mathrm{P}$ ratios (Segawa, 1956) R/P ratios (Feldmann, 1937) and $(\mathrm{R}+\mathrm{C}) / \mathrm{P}$ ratios (Cheney, 1977$)$ to analyze the flora characteristics of macroalgae and identify the changes in species composition according to geographic conditions. The macroalgae data were transformed into present-absence format for further analysis using Primer 6 software. Bray-Curtis Similarity Index similarity analyzes were performed to visualize differences in macroalgae species from the different Islands.

\section{Results and Discussion}

\subsection{Species Composition}

There are 41 species of macroalgae from the Pari Island reef cluster have been identified by taxonomist to the level of species originating from 25 genera and 18 families (Table 1). The lists of marine macroalgae species are shown in Table 2. In addition, there are 13 specimens were identified until the genera level and two variants of Caulerpa racemosa (var. macrophysa Kützing and var. peltata Turner Bosse), which not considered for our further analysis. The composition of macroalgae species was classified into three divisio, namely red macroalgae (Rhodophyta), green macroalgae (Chlorophyta), and brown macroalgae (Phaeophyta). Rhodophyta is the most diverse divisio of macroalgae with a total of 20 species (49\%) compared to Chlorophyta with 11 species (27\%) and Phaeophyta with 10 species (24\%).

Macroalgae have been classified by the

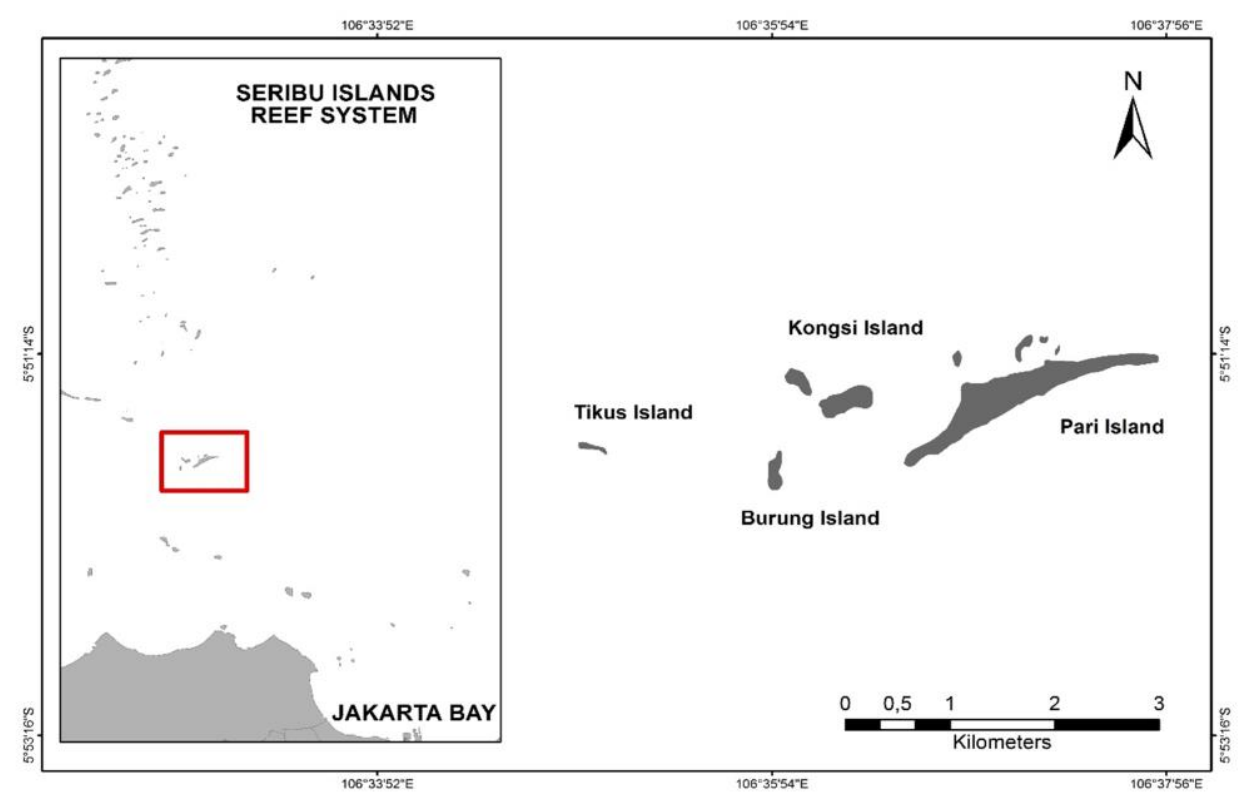

Figure 1. Study area map in Pari Island reef cluster 
ratio of Chlorophyta and Rhodophyta species relative to Phaeophyta species. The $\mathrm{C} / \mathrm{P}, \mathrm{R} / \mathrm{P}$, and $(\mathrm{R}+\mathrm{C}) / \mathrm{P}$ ratios were $1.1,2$, and 3.10 , respectively. Chlorophyta divisio were dominated by Caulerpa and Halimeda, while Rhodophyta division were dominated by Hypnea, Euchema, and Laurensia. In the case of Phaeophyta divisio, Sargassum was appeared as the dominant genus found in the sampling location.

In this study, it was found that Sargassum polycystum, Amphiroa fragilissima, and Halimeda opuntia were the dominant macroalgae species. The three species of macroalgae each represent the Phaeophyta, Rhodophyta and Chlorophyta divisions. A recent report by Srimariana et al. (2020) state that Halimeda macroloba, Halimeda opuntia, Gracilaria salicornia, Laurencia sp., and Padina minor are the dominant macroalgae species found on Pari Island. Based on the results of our data analysis, there were seven species of macroalgae on Pari Island that were confirmed to be rediscovered in Srimariana's research in 2020, namely Caulerpa racemosa, Caulerpa sertularioides, Halimeda macroloba, Halimeda opuntia, Ulva lactuca, Acanthophora spicifera, and Gracilaria salicornia. The 34 macroalgae species found in the previous study were not found in the 2020 study. However, there were 11 new macroalgae species found in the study by Srimariana et al. (2020), so that this can complement information about the diversity of macroalgae in the Pari Island cluster.

The number of macroalgae species found in this study have not been fully described the macroalgae diversity in Pari Island reef cluster because it does not reflect the entire of macroalgae seasons. However, combination of the number of macroalgae species in this report with the findings of Srimariana et al. (2020) has represented around $51 \%$ of the total macroalgae in the Seribu Islands. Kadi (2004) and Hutomo and Moosa (2005) recorded a total of 101 taxa macroalgae from the Seribu Islands. Significant number of macroalgae species in Seribu Islands and the Jakarta Bay was reported by Atmadja and Van Reine $(2010 ; 2014)$ where they collected a total of 145 species of macroalgae, consisting of 58 species of green macroalgae (19 genus), 55 species of red macroalgae (35 genus), and 32 species of brown macroalgae (16 genus). Unfortunately, that report does not provide detailed information regarding specific sites and macroalgae sampling season in the Seribu Islands and Jakarta Bay. Current information regarding the number of algal taxa in the Seribu Islands and Jakarta Bay also reported by Draisma et al. (2017) with 67 macroalgae taxa recorded from 27 islands in the Seribu Islands. The emergence of species and change of macroalgae composition could be related to the environmental factors dynamics (Sukiman et al., 2014) or unexplained investigation variance such as season (Bruckner and Dempsey, 2015; Shoubaky and Kaiser, 2014), depth of sampling (Kang et al., 2011) and competition (Kerswell, 2006). In general, the number of species and composition of all taxa differ significantly between periods and researchers.

\subsection{Macroalgae Distribution}

Species distribution varies greatly among the Islands, which may be caused by different substrate profiles and human disturbance. The highest macroalgae diversity were recorded in Kongsi Island with 33 species, followed by Tikus Island with 12 species, Burung Island has eight species, and Pari Island with five species. Pari Island has the smallest number of species compared to the other three islands. However, in terms of area dimension, Pari Island is the largest island in the Pari Island reef cluster that is an island with a large population compared to Kongsi Island, Burung Island and Tikus Island which are islands without inhabitants. The distribution of macroalgae species in the Pari Island reef cluster is given in Figure 2.

Table 1. Number of marine macroalgae taxa found in Pari Island reef cluster

\begin{tabular}{lcccc}
\hline Macroalgae & \multicolumn{3}{c}{ Number of Taxa } & \multirow{2}{*}{ Total } \\
\cline { 2 - 4 } Taxonomy & Chlorophyta & Phaeophyta & Rhodophyta & \\
\hline Family & 7 & 3 & 8 & 18 \\
Genus & 7 & 7 & 11 & 25 \\
Species & 11 & 10 & 20 & 41 \\
\hline
\end{tabular}


Table 2. Species list of marine macroalgae compared to Srimaryana et al. (2020)

\begin{tabular}{|c|c|c|c|c|c|}
\hline \multirow{2}{*}{ Division and Species } & \multicolumn{4}{|c|}{ Island } & \multirow{2}{*}{$\begin{array}{l}\text { Srimaryana et al. } \\
(2020)\end{array}$} \\
\hline & Kongsi & Burung & Pari & Tikus & \\
\hline \multicolumn{6}{|l|}{ Chlorophyta } \\
\hline Boodlea composita & + & + & - & - & - \\
\hline Caulerpa racemosa & + & + & - & - & + \\
\hline $\begin{array}{l}\text { Caulerpa racemosa v. macrophysa (Kützing) } \\
\text { Taylor }\end{array}$ & + & - & - & - & - \\
\hline Caulerpa racemosa var.peltata (Turner) Bosse & + & - & - & - & - \\
\hline Caulerpa sertularioides (Vahl) C. Agardh & + & - & - & - & + \\
\hline Codium adhaerens & + & - & - & - & - \\
\hline Halimeda macroloba Decaisne & + & - & - & + & + \\
\hline Halimeda micronesico & + & - & - & + & - \\
\hline Halimeda opuntia (Linnaeus) Lamouroux & + & + & - & + & + \\
\hline Tydemania expeditionis Weber Van Bosse & - & - & + & - & - \\
\hline Ulva lactuca Linnaeus & + & - & - & - & + \\
\hline Valonia macrophysa & + & - & - & - & - \\
\hline Valonia utricularis & + & - & - & - & - \\
\hline \multicolumn{6}{|l|}{ Phaeophyta } \\
\hline Colpomenia sinuosa (Roth) Derbes et Solier & - & - & + & - & - \\
\hline Dictyota dichotoma (Hudson) Lamouroux & + & - & - & - & - \\
\hline Hormophysa triquetra (C. Agardh) Kutzing & + & + & - & - & - \\
\hline Hydroclathrus clathratus (C. Agardh) Howe & - & - & - & + & - \\
\hline Padina australis Hauck & - & - & - & + & - \\
\hline Sargassum aquifolium & - & - & - & + & - \\
\hline Sargassum longifolium Agardh & + & - & - & - & - \\
\hline Sargassum polycystum C.A. Agardh & + & + & - & + & - \\
\hline Turbinaria decurrens Bory & - & - & - & + & - \\
\hline Turbinaria murrayana & + & - & - & - & - \\
\hline \multicolumn{6}{|l|}{ Rhodophyta } \\
\hline Acanthophora dendroides & + & - & - & - & - \\
\hline Acanthophora spicifera (Vahl) Boergesen & + & - & + & - & + \\
\hline Amphiroa fragilisima (Linnaeus) Lamouroux & + & - & + & + & - \\
\hline Chondria dasyphylla (Wood Ward) C. Agardh & - & - & - & + & - \\
\hline Chondrococcus hornemannii (Martens) Smitz & + & - & - & - & - \\
\hline Eucheuma spinosum (L) J. Agardh & + & - & + & - & - \\
\hline Eucheuma edule Kützing & + & - & - & - & - \\
\hline Eucheuma muricatum & + & - & - & - & - \\
\hline Gelidiella acerosa (Forsskål) Feldmann & + & - & - & + & - \\
\hline Gracilaria edulis (Gmelin) Silva & - & + & - & - & - \\
\hline Gracilaria salicornia (C. Agardh) Dawson & + & - & - & - & + \\
\hline Halymenia durvillaei Bory & + & - & - & - & - \\
\hline Hypnea cervicornis J. Agardh & - & + & - & - & - \\
\hline Hypnea cynomiceae & + & - & - & - & - \\
\hline Hypnea musciformis & + & - & - & - & - \\
\hline Hypnea nidulans Setchell & + & - & - & - & - \\
\hline Laurencia intricata & + & + & - & - & - \\
\hline Laurencia nidifica Agardh & + & - & - & - & - \\
\hline Laurencia obtusa (Hudson) Lamouroux & - & - & - & + & - \\
\hline Polysiphonia flexicaulis (Harvey) Coll. & + & - & - & - & - \\
\hline Number of species & 33 & 8 & 5 & 12 & \\
\hline
\end{tabular}

$+:$ Presence of species $\quad-:$ : Absence of species 


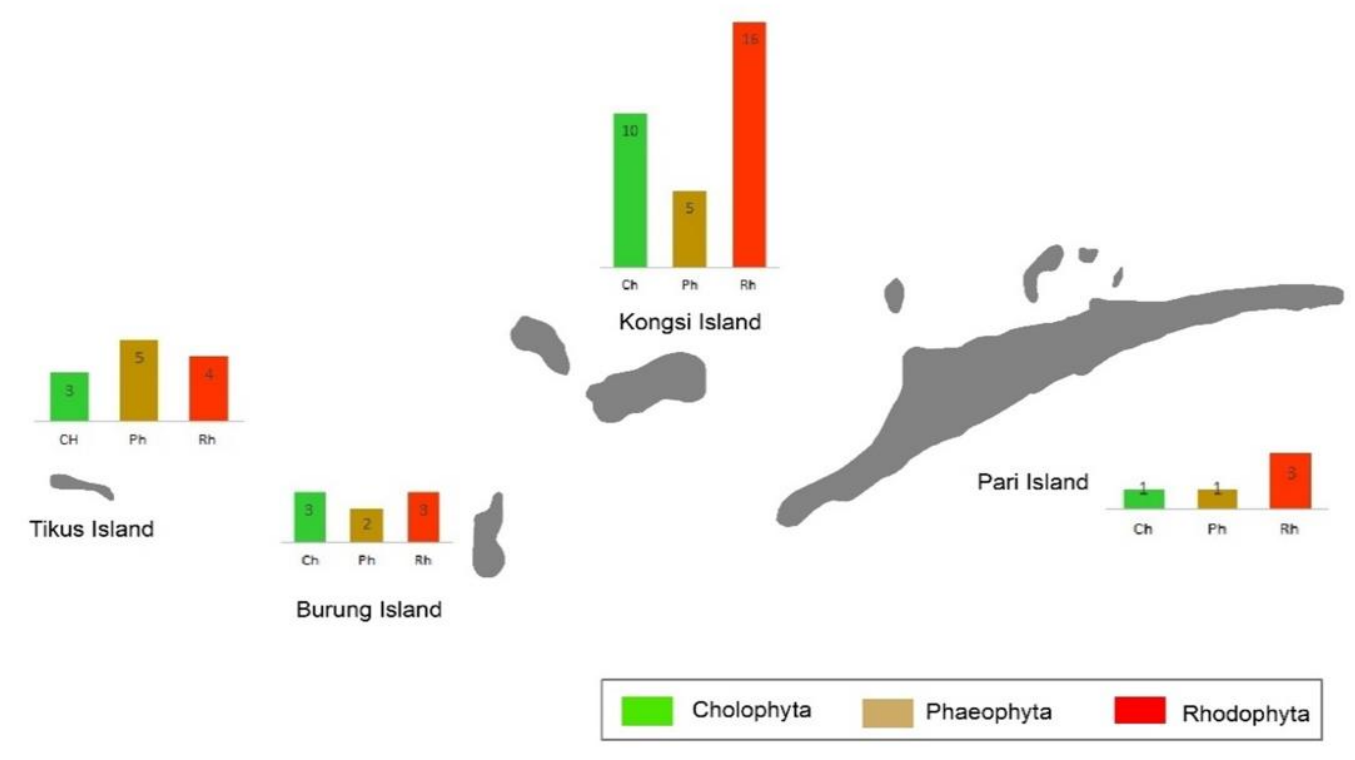

Figure 2. Distribution of marine macroalgae species in Pari Island reef cluster

The dominance of the Rhodophyta (Rh) division in three islands, namely in Pari Island $(60 \%)$, then on Kongsi Island (52\%) and the lowest on Burung island (37.5\%). The highest dominance of divisio Phaeophyta $(\mathrm{Ph})$ was in Tikus Island (42\%), then Burung Island (25\%), Pari Island (20\%), and the lowest was Kongsi Island (16\%). The divisio Cholophyta (Ch) is relatively scattered in all research locations, namely the highest is Burung Island (37.5\%), then Kongsi Island (32\%), Tikus Island (25\%) and the lowest is Pari Island (20\%). The dominance of the macroalgae divisions are given in Figure 3.

The relationship patterns of macroalgae species from the four islands studied were analyzed using Bray-Curtis similarity Index as shown in Table 3. Our analysis shows that the macroalgae species on Kongsi Island and Burung Island have highest similarity value is $29 \%$. While the macroalgae on Pari Island and Tikus Island have the lowest species similarity is $11.7 \%$. According to Wulandari et al. (2014), a similarity value close to $100 \%$ has a high level of similarity, and a value close to 0 means a lower level of similarity. Gerung et al. (2006) stated that the similarity of macroalgae species influenced by several factors, such as differences in the substrate as macroalgae habitat in the study site.

Figure 4 shows a cluster analysis of the dendrogram based on macroalgae species compositions. The dendrogram is divide into two groups corresponding to the island characteristics. Group one only consists of Pari Island, while group two divided into three subgroups. Pari Island was characterized by its distinctive environmental conditions by the presence of human disturbance. Group two, consists of Kongsi Island, Burung Island, and Tikus Island, which were characterized by similarities in terms of environmental conditions such as substrates composition and relatively low environmental pressures.
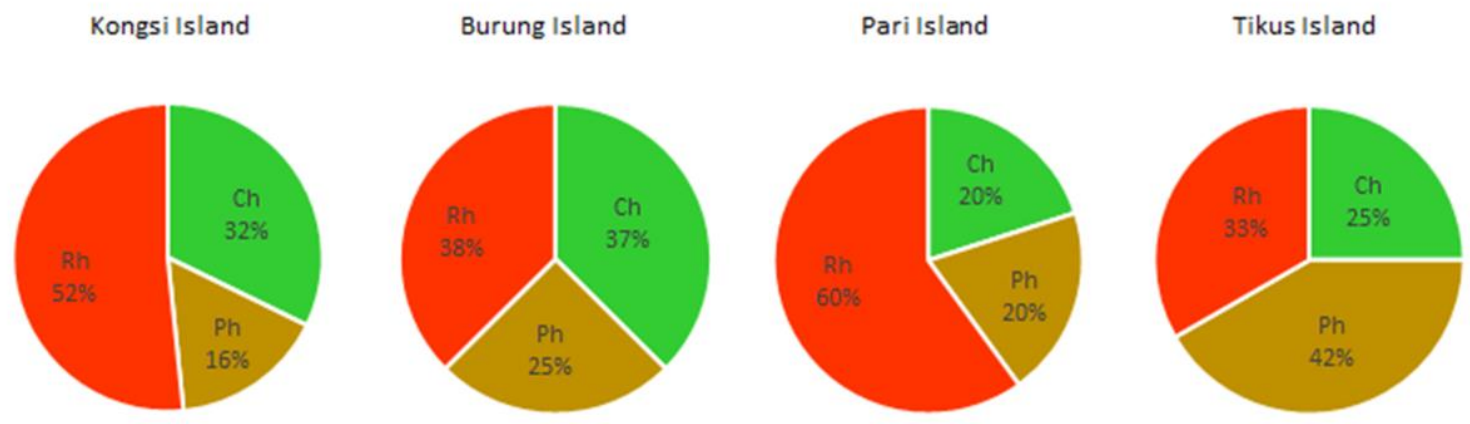

Figure 3. The dominance of the macroalgae divisions in the Pari Island reef cluster 


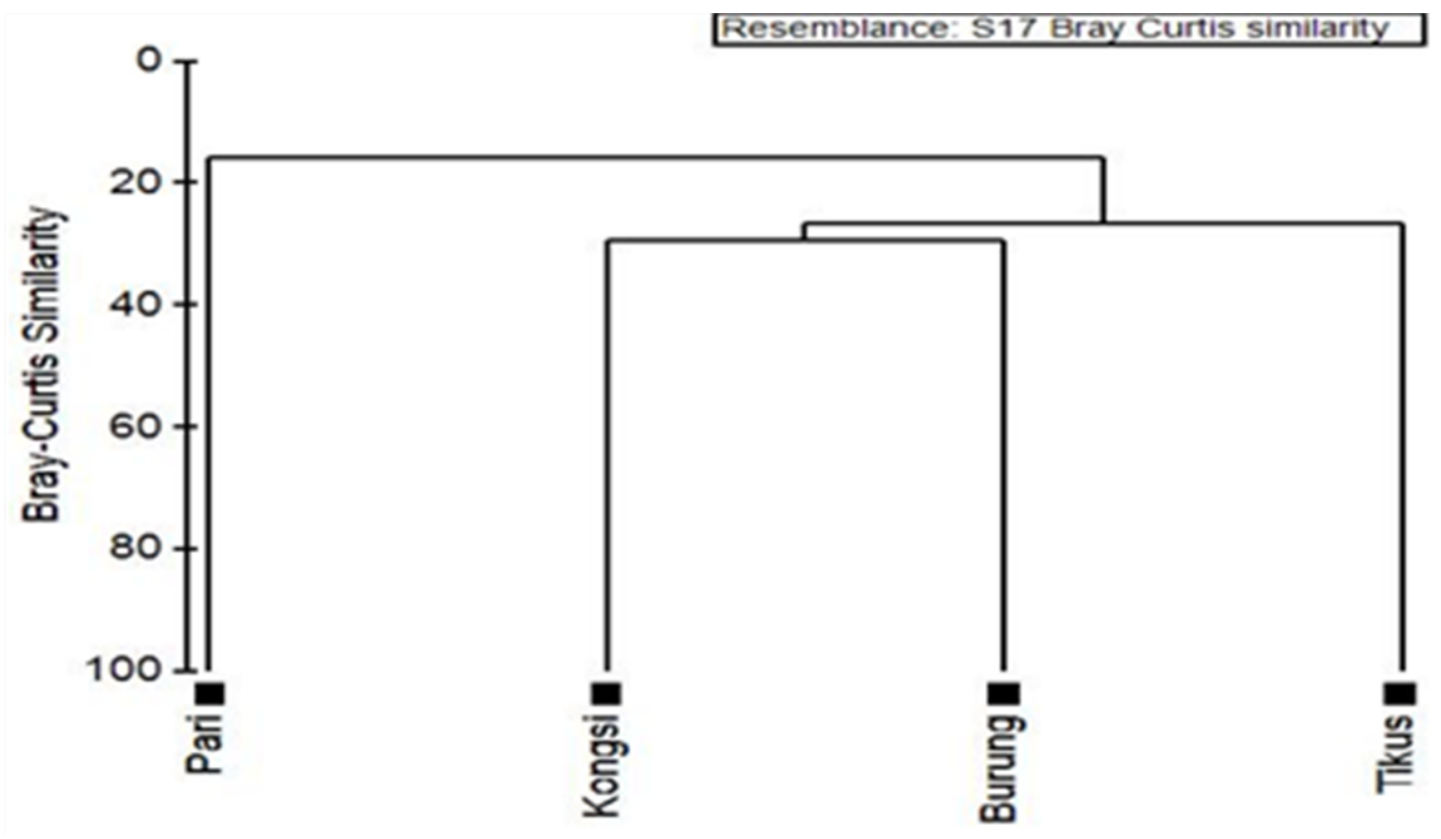

Figure 4. Dendrogram of marine macroalgae species compositions di Pari Island reef cluster.

The distance between Kongsi Island and Burung Island are close to one another. Therefore the environmental characteristics of the two islands are almost similar. There are six same species of macroalgae found on both islands, namely: Boodlea composita, Caulerpa racemosa, Halimeda opuntia, Hormophysa triquetra, Sargassum polycystum, and Laurencia intricata. Conversely, the distance between Pari Island and Tikus Island are far from each other with different environmental characteristics, types of island use, and levels of environmental stressor. There is only one same species of macroalgae found on both islands, namely Amphiroa fragilissima.

The distribution of macroalgae species in the Pari Island reef cluster appears to be correlated primarily with the substrate profile difference along the gradient of islands and is also affected by human disturbance. Each island has different substrate characteristics as a habitat for macroalgae growth. Different types of substrates and other environmental factors can affect the growth and macroalgae population in the intertidal zones (Zhao et al., 2016; Juul-Pedersen et al., 2008). Different types of substrates affect the growth ability of macroalgae species; therefore, it impacts species diversity in the area (Handayani, 2017). Kongsi Island has a mixture of substrates in the forming of sand, sandy mud, and gravel. Similar substrate types are also found in Burung Island and Tikus Island. Most of the macroalgae can grow on two different types of substrates. In coastal areas with sand and sandy mud substrate, Rhodophyta and Chlorophyta such as Gracilaria and Halimeda are common. Whereas on the coast with rocky substrate types, Phaeophyta, such as Sargassum and Turbinaria are often found (Handayani, 2017). Conversely, significant differences were found in Pari Island where the island is an inhabited island the settlements concentrated in the southern. This island has dynamic environmental conditions due to settlements, tourist activities, and jetties, which

Table 3. Bray-Curtis Similarity Index for marine macroalgae of study area

\begin{tabular}{lcccc}
\hline \multicolumn{1}{c}{ Island } & Kongsi & Burung & Pari & Tikus \\
\hline Kongsi & & & & \\
Burung & 29.26 & & & \\
Pari & 15.79 & 0 & & \\
Tikus & 26.67 & 20 & 11.76 & \\
\hline
\end{tabular}


cause pressure on the presence of macroalgae on the island. Intensive human activities in coastal zones could be resulting in massivescale changes in the abundance and distribution of species (Kim et al., 2010; Worm and Chapman A.R, 1996). Even more, the number of macroalgae species in natural distribution relatively low. Macroalgae are known to be vulnerable to physical and chemical changes in the marine environment (Harley et al., 2012) and threat by various human activities, particularly in developing countries (Satheesh and Wesley, 2012).

\subsection{Future Direction for Macroalgae Resources Management}

The high diversity of macroalgae in Pari Island reef cluster especially on Kongsi Island is essential to conserve. On the other hand, the Pari Island cluster is also one of the favorite tourist destinations in the Thousand Islands, as a result the pressure on the existence of marine life on the island is relatively high. Therefore, it requires more severe efforts to protect the existence of macroalgae resources. Macroalgae have an important ecological role as primary producers, provide food for herbivorous groups and support the lives of other related organisms (Mejia et al., 2012). Macroalgae are substantial species occupiers of rocky shores and interact with other organisms and hence play a key role in overall coastal biodiversity (Sanghvi et al., 2019). In addition, macroalgae provide physical protection to coastal areas and useful indicators of coastal water quality (Pereira and Neto, 2015). Because of their critical ecological roles, macroalgae require special attention by authorities to ensure an appropriate conservation strategy. Zoning systems for the conservation of macroalgae communities and other biological resources should be established to reduce the potential damage of coastal biodiversity (Zhao et al., 2016). The effort of scientific research needs to be continued to identify that macroalgae species that of high economic value. In addition, the understanding of macroalgae resource contribution to humans and coastal ecosystems should be socialized intensively to communities and tourists to encourage local awareness. Further study on the ecological aspect of macroalgae and other biological marine resources is essential not only for better management of marine ecosystems but also provides useful information for marine macroalgae conservation strategies in the Pari Island reef cluster.

\section{Conclusions}

The number of macroalgae species found on Kongsi Island, Tikus Island, Burung Island and Pari Island were 41 species of marine macroalgae where the largest macroalgae population is on Kongsi Island, then Tikus Island, Burung Island and the least is Pari Island. Rhodophyta Division is the division that dominates the four islands, then Chlorophyta and finally Phaeophyta. The distribution of macroalgae in the four islands that was observed was different, this was most likely caused by differences in environmental conditions and the presence of different environmental pressures. Proper management of macroalgae resources is needed to maintain the presence of macroalgae in the Pari Island cluster.

\section{Acknowledgements}

We are grateful to Atmadja, R. Surjodinoto, S. Poejiani S. Wijaya, Inan, Subagja W., and Kadi for their essential contributor in macroalgae sampling. We also wish to thank the staff of RCO-LIPI, Indonesia for access to the reference collection facility.

\section{References}

Atmadja, W. S., A. Kadi, Sulistijo, and Rachmaniar. 1996. Pengenalan jenisjenis rumput laut di Indonesia. Pusat Penelitian dan Pengembangan Oseanologi LIPI, Jakarta.191 pp.

Atmadja, W.S., Van Reine, W.F.P. 2010. Checklist of the Seaweed Species Biodiversity of Indonesia with Distribution and Classification: Red Algae (Rhodophyceae). Naturalis Biodiversity Center and Indonesian Institute of Sciences (LIPI), Jakarta. 72 pp.

Atmadja, W.S., Van Reine, W.F.P. 2014. Checklist of the Seaweed Species Biodiversity of Indonesia with Distribution and Classification: Green Algae (Chlorophyta) and Brown Algae (Phaeophyceae, Ochrophyta). Naturalis Biodiversity Center and Indonesian Institute of Sciences (LIPI), Jakarta. 59 pp.

Bruckner A.W., Dempsey A.C. 2015. The status, threats, and resilience of reefbuilding corals of the Saudi Arabian Red Sea. In: The Red Sea. Rasul N. M. A., Stewart I. C. F. (eds), Springer Earth System Sciences, pp. 471-486. DOI: 10.1007/978-3-662-45201-1_27. 
Cheney, D.P. 1977. R\&C/P - A new and improved ratio for comparing seaweed floras. Journal of Phycology. 13 (Suppl.): 129.

Draisma, S.G.A., Van Reine, W.F.P., Herandarudewi, S.M.C., Hoeksema, B.W. 2018. Macroalgal diversity along an inshore-offshore environmental gradient in the Jakarta Bay-Thousand Islands reef complex, Indonesia. Estuarine, Coastal and Shelf Science. 200: 258-269. https://doi.org/10.1016/j.ecss.2017.11.01 0 .

Feldmann, J. 1937. Recherches sur la vegetation marine de la Miditerranee. La cote des Alberes. Revue Algologique. 10: 1-339.

Gerung, G.S., Lokollo, F.F., Kusen, J.D., Harahap, A.P. 2006. Study on the seaweeds of Ambon Island, Indonesia. Coastal Marine Science. 30 (1): 162-166. http://doi.org/10.15083/00040768.

Handayani. 2017. The Potency of Macroalgae in the Reef Flat of Lampung Bay. Oseanologi dan Limnologi di Indonesia. 2(1):55-57

Harley, C.D.G., Anderson, K.M., Demes, K.W., Jorve, J.P., Kordas, R.L., Coyle, T.A., Graham, M.H. 2012. Effect of climate change on global seaweed communities. Phycological Society of America. 48 (5): 1064-1078. 8817.2012.01224.x

Hutomo, M., Moosa, M.K. 2005. Indonesian marine and coastal biodiversity: Present status. Indian Journal of Marine Sciences. 34(1): 88-97.

Juul-Pedersen, T., Michel, C., Gosselin, M. 2008. Influence of the Mackenzie River plume on the sinking export of particulate material on the shelf. Journal of Marine $\begin{array}{lll}\text { Systems. } \quad 74 & \text { (3): } \quad 810-824 .\end{array}$ https://doi.org/10.1016/j.jmarsys.2008.02. 001

Kadi, A. 2004. Potensi rumput laut di beberapa peraiaran pantai Indonesia. Oseana. 29 (4): 25-36.

Kang, J.C., Choi, H.G., Kim, M.S. 2011. Macroalgal species composition and seasonal variation in biomass on Udo, Jeju Island, Korea. Algae. 26(4): 333-342. DOI: 10.4490/algae.2011.26.4.333

Kerswell, A.P. 2006. Global biodiversity pattern of benthic marine algae. Ecology. 87(10), 2479-2488. https://doi.org/10.1890/00129658(2006)87[2479:GBPOBM]2.0.CO;2

Kim B.Y., Kim, W.S., and Choi, H.G. 2010. Seasonal variability of seaweed biomass along the vertical shore gradients of Nachido and Odo islands, the Yellow Sea, Korea. Fish Aquatic Sciences. 13 (4): 324-331. DOI: $10.5657 /$ fas.2010.13.4.324

Mejia, A.Y., Puncher, G.N., Engelen, A.H. 2012. Macroalgae in tropical marine coastal systems in: C. Wiencke and $\mathrm{K}$. Bischof (eds.), Seaweed Biology, Ecological Studies. Springer-Verlag Berlin Heidelberg. pp: 329-357.

Pereira, L., Neto, J.M. 2015. Marine Algae Biodiversity, Taxonomy, Environmental Assessment, and Biotechnology. CRC Press, Taylor \& Francis Group. 390 p.

Rachello-Dolmen, Cleary, D.F.R. 2007. Relating coral species traits to environmental conditions in the Jakarta Bay / Pulau Seribu reef system, Indonesia. Estuarine, Coastal and Shelf Science. 73 (3-4): 816-826. https://doi.org/10.1016/j.ecss.2007.03.01 7

Sahayaraj, K., Rajesh, S., Asha, A., Rathi, J. M., Raja, P. 2014. Distribution and diversity assessment of the marine macroalgae at four southern districts of Tamil Nadu, India. Indian Journal of GeoMarine Sciences. 43 (4): 607-617.

Salim, H., Ahmad. 2013. Karakteristik Pantai Gugusan Pulau Pari. Region. 5 (1): 1-11.

Sanghvi, D., Chaudhury, N.R., Jain, B. K. 2019. Macroalgae as indicator species for shore platform zones of Dwarka, Gujarat, India. Indian Journal of Geo-Marine Sciences. 48 (4): 416-422.

Satheesh, S., Wesley, S. G. 2012. Diversity and distribution of seaweeds in the Kudankulam coastal waters, SouthEastern coast of India. Biodiversity Journal. 3(1): 79-84.

Segawa, S. 1956.Coloured illustrations of the seaweeds of Japan. Hoikusha Publication. Co. Osaka. Pp: 1-175.

Simatupang, D.F., Yanty, J. S., Rachmayanti, Y., Warganegara, F. M., Akhmaloka. 2018. Diversity of Tropical Marine Macroalgae from Coastal Area of Sayang Diversity of Tropical Marine Macroalgae from Coastal Area of Sayang Heulang, West Java Indonesia. Biosciences Biotechnology Research Asia. 15 (1): 139-144. DOI: 10.13005/bbra/2616

Srimariana, E.S., Kawaroe, M., Lestari, D. F., Setyaningsih, W. A., Nugraha, A. H. 2020. Biodiversity of macroalgae in Pari Island Biodiversity of macroalgae in Pari Island. IOP Conference Series: Earth and 
Environmental Science. 429012018. DOI: 10.1088/1755-1315/429/1/012018

Sudhakar, K., Mamat, R., Samykano, M., Azmi, W.H., Ishak, W.F.W., Yusaf, T. 2018. An overview of marine macroalgae as bioresource. Renewable and Sustainable Energy Reviews. 91 (C):165179.

Sukiman, Muspiah, A., Astuti, S.P., Ahyadi, H., Aryant, E. 2014. Keanekaragaman dan Distribusi Spesies Makroalga Di Wilayah Sekotong Lombok Barat. Jurnal Penelitian UNRAM. 18 (2): 71-81.

Worm, B., Chapman A. R. 1996. Interference competition among two intertidal seaweeds: Chondrus crispus strongly affects survival of Fucus evanescens recruits. Marine ecology progress series. 145: 297-301.

Wulandari, D.Y., Tunjung, Pratiwi, N.T.M., Adiwilaga, E.M. 2014. Distribusi Spasial Fitoplankton di Perairan Pesisir Tangerang (Spatial Distribution of Phytoplankton in the Coast of Tangerang). Jurnal IImu Pertanian Indonesia. 19 (3): 156-162.

Zhao, F., Xu, N., Zhou, R., Ma, M., Luo, H., Wang, H. 2016. Community structure and species diversity of intertidal benthic macroalgae in Fengming Island, Dalian. Acta Ecologica Sinica. 36: 77-84. http://dx.doi.org/10.1016/j.chnaes.2016.0 1.004 